\title{
WATER NEBULIZATION IN A NON-REBREATHING SYSTEM DURING ANAESTHESIA
}

\author{
M. Azad TaYyaB, M.B., F.F.A.R.c.s., \\ M. Ambiavagar, M.B., F.F.A.R.C.S., ANd J. Chalon, M.D. ${ }^{*}$
}

\section{INTRODUCTION}

Dry anaesthetic gases damage tracheobronchial ciliated epithelium after one hour of administration. ${ }^{1}$ In contrast it was found that gases saturated with water vapour at body temperature or an inhaled mixture with a 60 per cent relative humidity at room temperature $\left(22-26^{\circ} \mathrm{C}\right)$ do not produce cellular damage during a three-hour study period.

This investigation analyzes the effects of inhaling anaesthetic gases humidified by an efficient cold water nebulizer. $+\mathrm{A}$ comparison is made between the tracheobronchial cytology of patients inhaling dry gases, gases humidified with this cold water nebulizer and gases humidified with water vapour.

A system incorporating a compressed gas nebulizer in a nonrebreathing system was developed in order to conduct this study. This system will be described and its characteristics discussed.

\section{Patients ANd Methods}

This study was carried out on nine patients who had given their informed consent. All were non-smokers and free from cardiopulmonary disease. General anaesthesia with tracheal intubation was clinically indicated. All procedures lasted more than three hours. Premedication was pentobarbitone or secobarbitone $2 \mathrm{mg} / \mathrm{Kg}$ body weight or meperidine $1.5 \mathrm{mg} / \mathrm{Kg}$ administered intramuscularly. Belladonna alkaloids were not used because they interfere with mucociliary functions. The trachea was intubated during succinylcholine apnoea after induction with thiopentone $(3 \mathrm{mg} / \mathrm{Kg})$. Anaesthesia was maintained with 70 per cent nitrous oxide in oxygen. d-Tubocurarine, $0.4 \mathrm{mg} / \mathrm{Kg}$ was administered initially with supplemental doses of 3 to $6 \mathrm{mg}$ as required. Meperidine was given in unit doses of 10 to $20 \mathrm{mg}$ intravenously and repeated as needed.

Saline tracheobronchial washings were obtained at the onset of anaesthesia and at hourly intervals thereafter, by instilling $3 \mathrm{ml}$ of physiologic saline into the tracheal tube, ventslating for 30 seconds and then suctioning. The transparent suction catheier was then cut at points where secretions were present. These were removed, spread on microscope slides, spray fixed, stained (Papanicolaou) and examined microscopically. 10461.

"From the Department of Anesthesiology, Albert Einstein College of Medicine, Bronx, N.Y.

†The term nebulizer used in this context describes a system with an output of liquid droplets that maintain measurable stability as a suspension in mixtures of medically administered gases.

Canad. Anaesth. Soc. J., vol. 20, no. 6, November 1973 


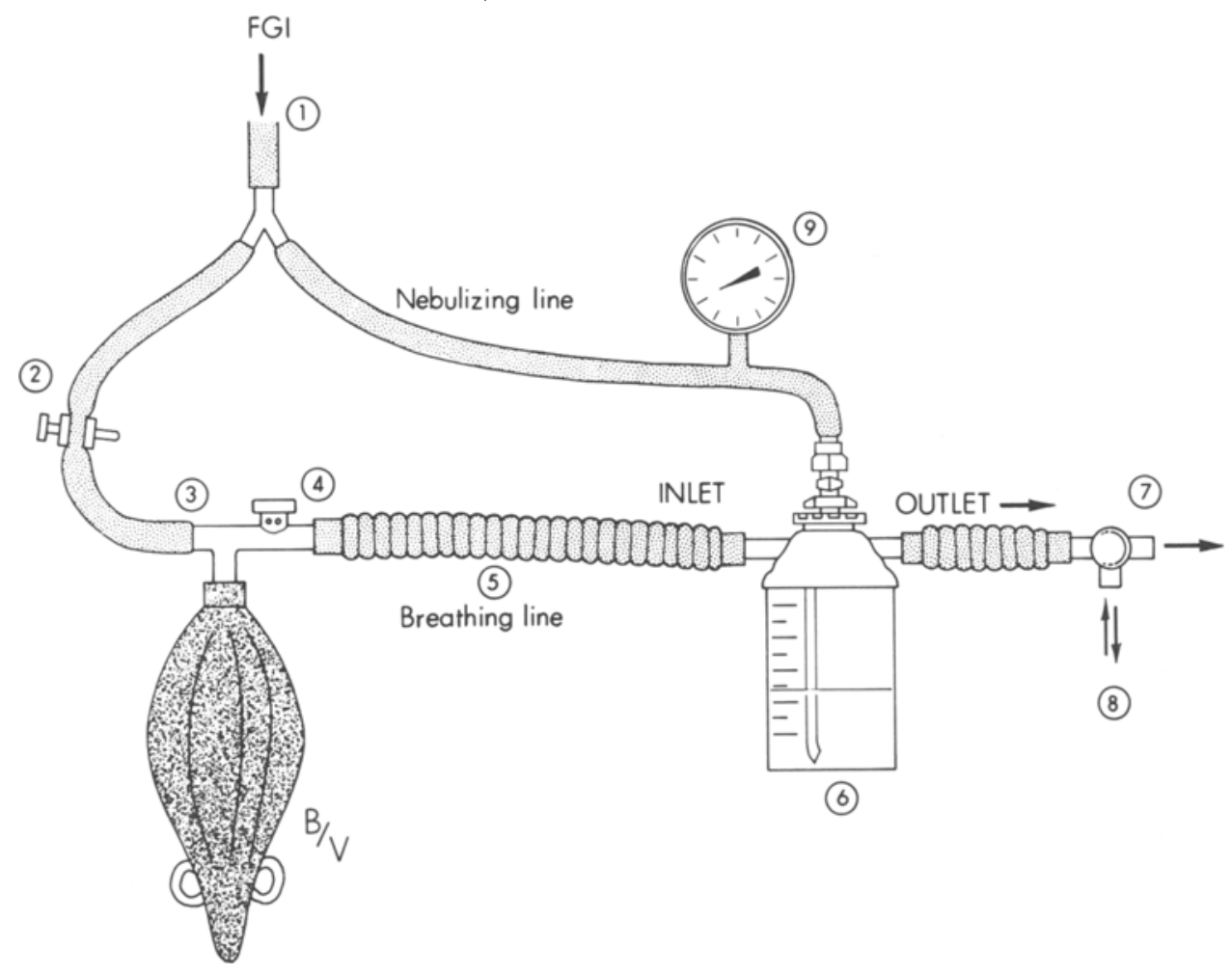

Frgure 1. System designed for clinical use. (1) Fresh gas inflow from anaesthetic machine at $Y$ piece, (2) adjustable clamp on tubing connected to Mapleson E System. (3) (4) and (5) components of Mapleson E System (3: T piece, 4: pop-off valve, 5: 90 -cm-long breathing tube), B/V breathing bag or ventilator, (6) $500 \mathrm{ml}$ Bird Nebulizer, (7) Ruben Valve, (8) patient connection, (9) anaeroid manometer on nebulizing line.

Cellular morphologic integrity was assessed and results expressed by a points scoring system in which each tracheobronchial ciliated cell examined can score from 0 to 6 points according to: (1) presence of cilia, (2) presence of end plate, (3) normal cytoplasmic colour (blue), (4) normal cytoplasmic shape and texture, (5) normal nuclear size, and (6) normal nuclear shape and texture. ${ }^{1}$ As 200 cells were examined in each group of slides obtained from the same tracheobronchial washing, the total score per smear could be from 0 to 1200 . To avoid possible observer error, specimens were examined by the same investigator (J.C.) in all studies. The Chi square method was used for statistical analysis, comparing mean scores of specimens obtained at the same hourly interval after the onset of anaesthesia with that of the first and every preceding specimen, thus permitting evaluation of changes in score at hourly intervals and with the control.

The anaesthesia system used was constructed by placing a $500 \mathrm{ml}$ Bird Nebulizer" in line between a Mapleson E System and a Ruben Nonrebreathing Valve (Figure 1). Fresh gas mixtures from the anaesthetic machine were delivered to the system through a $Y$ piece which divided the gas stream between the circuit of the ventilator or breathing bag (breathing line) and that of the nebulizer

"Bird Corporation. Catalogue number 9993-890. Palm Springs, California. 


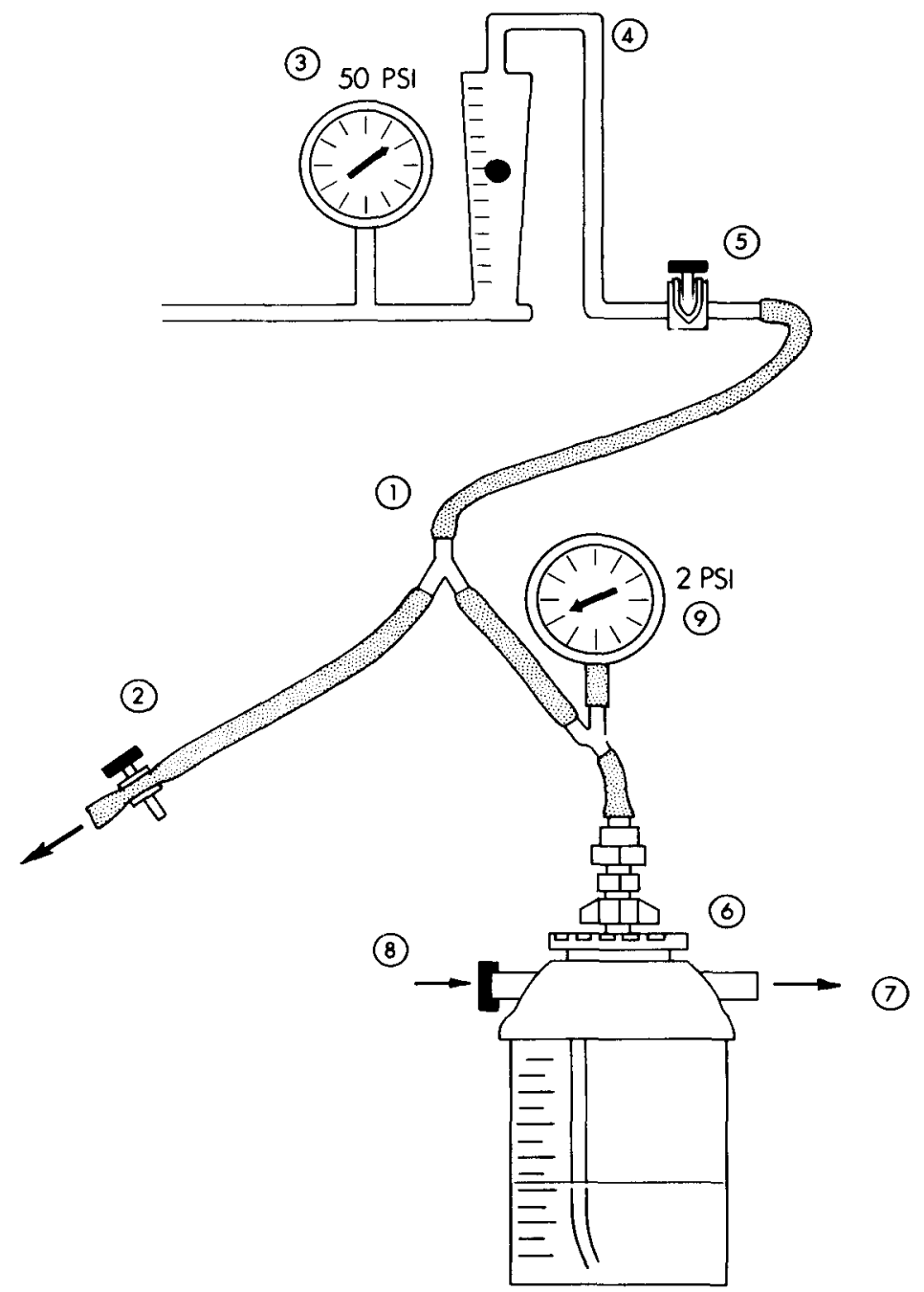

Figure 2. System designed to measure distribution of fresh gas inflow between breathing line and nebulizing line and to test the nebulizer. (1) Fresh gas inflow at $Y$ piece, (2) adjustable clamp on line venting to atmosphere, (3), (4), (5) metered source of fresh gas (3: anaeroid manometer indicating supply line pressure, 4: measuring column of flow meter, 5: control valve), (6) nebulizer, (7) outlet of nebulizer connected to a Collins Spirometer, (8) closed inlet of nebulizer, (9) anaeroid manometer.

(nebulizing line). An adjustable clamp was placed on the tubing joining the $Y$ piece to the breathing line and a calibrated anaeroid manometer inserted on the nebulizing line. The system was tested by placing a $5 \mathrm{~L}$ anaesthetic bag at the distal end of the Ruben Valve and ventilating it with an Airshields Ventimeter Ventilator. The adjustable clamp was gradually tightened to a point when the nebulizer just began to function and minimum nebulizing pressure was noted on the manometer.

Minimum nebulizing flow rate was also measured. To accomplish this, the 
TABLE I

Total Cellulak Score in Tracheobronchial

IIAshings from Patients in the Present STUdy at Hourly Intervals NS $=$ NOT SIGNIFICANT

\begin{tabular}{|c|c|c|c|c|}
\hline Group & $\mathrm{N}$ & $\overline{\mathrm{X}}$ & $\mathrm{SD}$ & $\mathrm{P}$ \\
\hline $\begin{array}{l}\text { Nebulized Water } \\
\text { Control }\end{array}$ & 6 & 950 & & 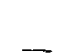 \\
\hline 1 hour & & $\begin{array}{l}900 \\
936\end{array}$ & $\begin{array}{l}49 \\
63\end{array}$ & $\overrightarrow{\mathrm{NS}}$ \\
\hline 2 hours & & 945 & 56 & NS \\
\hline 3 hours & & 941 & 49 & NS \\
\hline
\end{tabular}

system was removed from the anaesthetic machine and its $Y$ piece connected to a pressure compensated oxygen flow meter (Figure 2) calibrated at a line pressure of 3.4 atmospheres ( $50 \mathrm{psi}$ ). The Mapleson E portion of the circuit was then removed, the inlet of the nebulizer closed off with a rubber stopper and its outlet connected to a Collins Spirometer. The adjustable clamp on the tubing which had previously led to the Mapleson E System was gradually tightened, using a $15 \mathrm{~L} / \mathrm{min}$ fresh oxygen inflow, until minimum nebulizing pressure was reached, and minimum nebulizing flow rate recorded on the Collins Spirometer. Measurements were repeated using five different Bird Nebulizers.

The size and number of nebulized droplets at minimum nebulizing pressure was measured by connecting the nebulizer to a Bausch and Lomb 40-1 Light Scattering Device tat a fresh oxygen inflow rate of $15 \mathrm{~L} / \mathrm{min}$ (from the pressure compensated oxygen flow meter). The degree of light scatter from the droplets carried into this device is transduced by photoelectric sensors, amplified and measured by a computer resulting in a print out of droplet size and number.

The humidity of gases emerging from the corrugated tube of the ventilator was measured before and after each procedure with a Hygrodynamics Electric $\mathbf{H y}$ grometer Indicator.t

The volume of water expended in the nebulizer during three hours of anaesthesia was measured gravimetrically.

All anaesthesia equipment proximal to the nebulizer, including the ventilator, was thoroughly dried before anaesthesia by flushing it with dry gases for periods in excess of six hours.

Bacterial cultures of swabs from the Mapleson E System and inner surface of the bellows of the ventilator at the onset and end of anaesthesia, were examined.

Three of the nine patients were excluded from the study because one or more of their specimens contained less than 200 ciliated cells. Four of the patients in the study were females and two were males. The age range was from 33 to 73 years.

The mean cellular scores of smears obtained in the present study at the onset of anaesthesia (Table I) is of the order of $950 \pm 49$ and is maintained throughout anaesthesia, being $941 \pm 49$ (not significant) after three hours.

'Warren E. Collins, Boston, Mass. Model 909.

†Bausch and Lomb, Inc., Rochester, N.Y.

\$Hydrodynamics, Inc., Silver Springs, Md. Model 15-3001. 


\section{TABLE II}

Total Cellular Scores from Previous Study at Hourly Intervals. The Patients Breathed Dry Gases, Gases with a 60 Per Cent Relative Humidity at RoOM TEMperature, and Gases Saturated With Water Vapour at Body Temperature N.S. = NOT SIGNIFICANT

\begin{tabular}{|c|c|c|c|c|}
\hline Group & $\mathrm{N}$ & $\overline{\mathrm{X}}$ & $\mathrm{SD}$ & $\mathrm{P}$ \\
\hline $\begin{array}{l}\text { Dry Gases } \\
\text { Control } \\
1 \text { hour } \\
2 \text { hours } \\
3 \text { hours }\end{array}$ & 6 & $\begin{array}{r}1043 \\
920 \\
751 \\
579\end{array}$ & $\begin{array}{r}90 \\
152 \\
195 \\
239\end{array}$ & $\begin{array}{c}\overline{N S} \\
<0.01 \\
<0.01\end{array}$ \\
\hline $\begin{array}{c}60 \text { per cent } \\
\text { Humidity } \\
\left(22-26^{\circ} \mathrm{C}\right)\end{array}$ & 6 & & & \\
\hline $\begin{array}{l}\text { Control } \\
1 \text { hour } \\
2 \text { hours } \\
3 \text { hours }\end{array}$ & & $\begin{array}{r}1070 \\
973 \\
944 \\
925\end{array}$ & $\begin{array}{r}90 \\
161 \\
150 \\
163\end{array}$ & $\begin{array}{l}-\overline{N S} \\
\text { NS } \\
\text { NS }\end{array}$ \\
\hline $\begin{array}{l}\text { Saturated Humidity } \\
37^{\circ} \mathrm{C} \\
\text { Control } \\
1 \text { hour } \\
2 \text { hours } \\
3 \text { hours }\end{array}$ & 6 & $\begin{array}{l}1112 \\
1097 \\
1073 \\
1103\end{array}$ & $\begin{array}{l}33 \\
70 \\
91 \\
71\end{array}$ & $\begin{array}{l}-\overline{N S} \\
\text { NS } \\
\text { NS }\end{array}$ \\
\hline
\end{tabular}

The results from a previous study ${ }^{1}$ are presented for comparison (Table II). The mean fresh gas inflow to maintain ventilation during anaesthesia was $15 \pm$ $1 \mathrm{~L} / \mathrm{min}$ ( 840 to $860 \mathrm{~L} /$ hour). The amount of water expended in the nebulizer during three hours of anaesthesia was $48 \pm 3 \mathrm{ml}$ ( $16 \pm \mathrm{ml} /$ hour). Since the fresh gas inflow used was $15 \pm 1 \mathrm{~L} / \mathrm{min}$, each cubic meter of fresh gas will have removed $17.8 \pm 2.2 \mathrm{gms}$ of water from the nebulizer, corresponding to $78-100$ per cent relative humidity at $23^{\circ} \mathrm{C}$.*

Nebulization started in the nebulizer when nebulizing line pressure reached $105 \pm 4$ torr (minimum nebulizing pressure). Minimum nebulizing flow rate at this pressure, measured on the Collins Spirometer, was found to be $2.05 \pm 0.05$ $\mathrm{L} / \mathrm{min}$.

At a nebulizing flow rate of $2 \mathrm{~L} / \mathrm{min}$ and total flow of $15 \mathrm{~L} / \mathrm{min}$, the flow in the breathing line was therefore $13 \mathrm{~L} / \mathrm{min}$. At these settings more than one million droplets per cubic foot were nebulized. Ninety-five per cent of these droplets were 0.5 to 3 microns in diameter and the remainder were 3 to 5 microns. There were no droplets larger than 5 microns.

The lowest relative humidity reading on our hygrometer is 2 per cent at 22$26^{\circ} \mathrm{C}$ which for all practical purposes can be considered as dryness. Gases emerging from the corrugated tube of the ventilator before and after three hours of anaesthesia remained at that reading.

${ }^{\circ}$ One hundred per cent humidity at $23^{\circ} \mathrm{C}=20 \mathrm{gm} \mathrm{H}_{2} \mathrm{O} / \mathrm{M}^{3}$ of gas (or $20 \mathrm{mgm}$ of water per liter of gas).

$17.8 \pm 2.2 \mathrm{gm} \mathrm{H}_{2} \mathrm{O} / \mathrm{M}^{3}$ gas $=15.6-20 \mathrm{gm} \mathrm{H}_{2} \mathrm{O} / \mathrm{M}^{3}$ gas

(1) $20 \mathrm{gm} \mathrm{H} \mathrm{H}_{2} \mathrm{O} / \mathrm{M}^{3}$ gas $=100$ per cent humidity at $23^{\circ} \mathrm{C}$

(2) $15.6 / 20 \times 100=78$ per cent relative humidity at $23^{\circ} \mathrm{C}$. 


\section{Discussion}

Nebulized water apparently protects tracheobronchial ciliated epithelium. There is a drop of 9 points in the mean cellular score, from a control of 950 after three hours of anaesthesia (Table I). This represents a 1 per cent drop in score, meaning that normal cellular factors seen after anaesthesia have diminished by 1 per cent from the control values and can be expressed as a 1 per cent rate of cellular decay. It is apparent from Table II that 60 per cent relative humidity resulted in a rate of cellular decay of 13 per cent and that present figures are comparable with those in patients inhaling gases saturated with water vapour at body temperature when the rate of cellular decay was also 1 per cent.

No claim to statistical significance is possible from these figures, but it is reasonable to deduce that water droplets are as efficient as water vapour in preventing damage to the ciliated columnar cells of the tracheobronchial tree. This is in marked contrast with the rate of cellular decay of 45 per cent seen in specimens from patients who had inhaled dry anaesthetic gases for three hours $(\mathrm{P}<0.01)$. Although the mean cellular scores of the controls in this study (Figure 1) is lower than those noted in the original work (Figure 2), the difference is not statistically significant.

Flow-meters may be uncompensated for pressure if the control valve is placed proximal to the measuring column ${ }^{2}$ and compensated for pressure if the control valve is placed distal to their measuring column. Uncompensated flow meters are calibrated at atmospheric pressure and are therefore affected by increases in pressure distal to them. Pressure compensated flow-meters being calibrated at the pressure of the supply line are only affected by variations in pressure in that line. A flow meter placed on the nebulizing line of our system (Figure 2) would have been subjected to variations in both the supply and delivery lines when the clamp on the vent was adjusted and would, therefore, not have given accurate readings. For that reason it was decided to insert a pressure gauge instead of a flow meter. A pressure line of 105 torr was associated with a flow of $2.05 \mathrm{~L} / \mathrm{min}$ and a resistance at the jet of the nebulizer of $105 / 2.05=52$ torr per litre of gas per minute. As this measurement is based on the fact that resistance $=$ pressure $/$ flow (Ohm's Law), there is a linear relationship between variations in flow and pressure. Therefore, line pressure gives an exact measure of flow rate if the nebulizer is not altered structurally.

The nebulizer was mounted as near as possible to the patient to avoid wetting the equipment proximal to this instrument and especially ventilators, which are so difficult to sterilize. Water encourages bacterial growth and increases the risk of contamination of anaesthetic equipment. While infection of patients from contaminated anaesthetic apparatus may be difficult to prove, several authors ${ }^{3,4,5}$ have suggested its existence. We feel that it will become mandatory in time to offer patient protection through the use of sterile anaesthetic equipment and that avoiding unnecessary wetting of apparatus is a first step in that direction. In this system, some reflux from the nebulizer takes place during expiration, but this does not extend beyond the breathing tube of the Mapleson E System. During exhalation and the expiratory pause, flow through the nebulizer continues at a 
rate of $2 \mathrm{~L} / \mathrm{min}$. Fresh gas inflow in the breathing line fills the bellows of the ventilator. With a flow rate of $13 \mathrm{~L} / \mathrm{min}$ in that line, the bellows will be inflated in 3 seconds, after which fresh gas flows towards the nebulizer. The volume of reflux from the nebulizing flow of $2 \mathrm{~L} / \mathrm{min}$ during these 3 seconds is $100 \mathrm{ml}$. The 90-cm-long breathing tube has a volume of $284 \mathrm{ml}$. The wet gas inflowing in that tube during these three seconds should, therefore, not extend beyond its proximal end. This assumption is confirmed by the fact that the ventilator does not increase its moisture content during anaesthesia. We feel that active bacterial growth can only take place in the equipment that has been wet (breathing tube, nebulizer and nonrebreathing valve) and that one can therefore restrict sterilization between cases to that portion of the system.

Because of the very high flows necessary in this system, we feel that it should be restricted to anaesthesia with nitrous oxide and oxygen. There is of course no contraindication to the introduction of other volatile agents, but if they are used, it would seem almost mandatory to connect the exhalation port of the Ruben Valve to a venting line.

The cost of the high gas inflow is partly offset by the low cost of sterilization and avoidance of expensive disposable equipment.

\section{SUMMARY}

Humidity protects the integrity of the tracheobronchial mucociliary system during anaesthesia. ${ }^{3}$ This study compares humidification by heat versus nebulization.

A simple, practical and inexpensive circuit incorporating an efficient medical nebulizer was designed. It was deemed essential to build in features which would minimize the risk of bacterial contamination of the major components of the anaesthesia system, anaesthesia machine and automatic ventilator.

Cytologic studies demonstrated that the tracheobronchial ciliated epithelial cells of patients placed on this system for as long as three hours did not suffer morphologically.

In addition, no water reached the ventilator which remained dry and bacteriologically sterile.

\section{RÉSUMÉ}

Lhumidification des gaz anesthésiques protège les cellules trachéobronchiales durant l'anesthésie. ${ }^{1}$ Cette étude compare l'humidification thermale à la vaporisation.

Un circuit simple, pratique, peu côuteux et comprenant un vaporisateur médical fut construit. Il fut considéré essentiel d'inclure dans la construction des traits de dessin capables de réduire le risque de contamination bactérienne du système d'anesthésie, de la machine d'anesthésie et du ventilateur automatique.

Des études cytologiques ont demontré que les cellules trachéobronchiales ciliées des malades placés sur ce système sont restées morphologiquement intactes pendant trois heures d'anesthésie. 
De plus, les ventilateurs employés sur ces malades sont restés secs et bactériologiquement stériles.

\section{REFERENCES}

1. Chalon, J., Loew, D.A.Y., \& Malebranche, J. Effects of dry anesthetic gases on tracheobronchial ciliated epithelium. Anesthesiology 37: 334-343 (1972).

2. Adriani, J. The chemistry and physics of anesthesia. p. 104. Second edition. Charles C. Thomas, Publisher. Springfield, Illinois (1967).

3. MofFet, H.L. \& Williams, T. Bacteria recovered from distilled water and inhalation therapy equipment. Amer. J. Dis. Child. 114: 7-12 (1967).

4. Dryden, G.E. Risk of contamination from anesthesia circle absorber: an evaluation. Anesth. \& Analg. 48: 939-943 (1969).

5. JosEph, J.M. Disease transmission by inefficiently sanitized anesthesiology apparatus. J.A.M.A. 149: 1196-1198 (1952). 